Research Article

\title{
GENETIC VARIATION, HERITABILITY AND GENETIC ADVANCE IN SOME PROMISING RICE HYBRIDS
}

\author{
L.F. Lipi ${ }^{1}$, M.J. Hasan ${ }^{1}$, A. Akter ${ }^{1}$, M.R. Quddus ${ }^{1}$, P. L. Biswas ${ }^{1}$ \\ A. Ansari ${ }^{1}$ and S. Akter ${ }^{2}$ \\ ${ }^{1}$ Hybrid Rice Division, ${ }^{2}$ Plant Physiology Division \\ Bangladesh Rice Research Institute (BRRI) \\ Gazipur, Bangladesh
}

\begin{abstract}
Eleven rice hybrids including two check varieties were evaluated to approximate their genetic variability, heritability and genetic advance for ten quantitative traits. The analysis of variance illustrated that all the quantitative traits differed significantly indicating that enough variation is presenting the studied materials. Among the desirable quantitative traits number of filled spikelet's per panicle was found to have highest both phenotypic and genotypic variance followed by total number of spikelet's per panicle. Almost all the characters showed a little variation between PCV and GCV revealing little influence of the environment on the expression of traits. High phenotypic and genotypic variance coupled with high heritability and high genetic advance was observed for number of filled spikelet's per panicle, total number of spikelet's per panicle, plant height and number of unfilled spikelet's per panicle. Such findings stipulated that these traits were governed by additive gene actions which are fixable and these traits may be accounted for reliable index of selection. The genotypes G3 $($ IR79156A $\times$ EL108R) and G6 (IR79156A $\times$ EL253R) were selected as high response superior promising rice hybrids for achievable yield advantage $49 \%$ and $23 \%$, respectively over best check varieties. Therefore, the $\mathrm{G} 3$ and $\mathrm{G} 6$ are proposed to be extensively evaluated for further trial of variety release.
\end{abstract}

Keywords: Genetic advance, Rice Hybrid, Heritability, Variability

\section{INTRODUCTION}

Sustainable food security is pivotal for the wellbeing of a nation. Now, food security is threatened by a climate change, growing population, the loss of arable land to urbanization and reducing productivity. Food security predominantly depends on

*Corresponding Author: ferdousi.lipi@ yahoo.com 
rice production as it is the staple food for many nations in the world. Rice is one of the most important food crops in the world, supporting $21 \%$ of the total calorie intake of the world population and up to $76 \%$ of that of Southeast Asia (Miura et al., 2011). The production rate has gradually plateau because of the present yield ceiling of high yielding varieties. Hybrid rice, therefore is an evidence of vertical rice production technology (Oryza sativa L.), which could be a potential technological option for food security. About 77.07 \% of total cropped area of Bangladesh is used for rice production, whereas 0.7 Mha covered by hybrid rice (AIS, 2018). Two breakthroughs that led to quantum leaps in productivity last century were the introduction of semi dwarf varieties and hybrid rice (Qian et al., 2016). The genus Oryza can grow in diversified climatic conditions. The genus Oryza displays a wide range of genetic and phenotypic diversity because this wide range of growing habitat under diverse climatic conditions (Childs, 2004). Genetic variability, heritability and genetic advance and QTLs mapping in ice has been studied (Laxuman et al., 2010, Abebe et al., 2017; Laxmi et al., 2019) to analyze the different traits for crop improvement. Grain yield is a complex trait, controlled by polygene's which are highly influenced by environment. Therefore, it is difficult to anticipate whether the variability is heritable. However, in deciding the response to selection, the heritability of a genetic trait is very important as it implies the magnitude of the transmissibility of that trait to next generations. Alternatively, high genetic advance as percent of mean coupled with high heritability provides the most effective selection condition for a specific trait (Larik and Rajput, 2000). However, the present study aimed to estimate the genetic parameters (genotypic and phenotypic coefficient of variation, heritability and genetic advance) among quantitative traits which are helpful in exposing and understanding the clear picture of existing variability in the genotypes as well as to identify the promising genotypes for further advancement of breeding trial.

\section{MATERIALS AND METHODS \\ Experimental site, plant materials and experimental design and procedures}

The present study comprised of nine $F_{1}$ promising rice hybrids, combinations of BRRI35A $\times$ EL108R (G1), BRRI48A × EL108R (G2), IR79156A × EL108R (G3), BRRI35A $\times$ EL253R (G4), BRRI48A $\times$ EL253R (G5), IR79156A $\times$ EL253R (G6), BRRI35A $\times$ EL254R $(G 7)$, BRRI48A $\times$ EL254R $(G 8)$ and IR79156A $\times$ EL254R (G9) and two check varieties namely BRRI hybrid dhan4 (G10) and BRRI hybrid dhan6 (G11). The material was planted in Randomized Complete Block Design (RCBD) with three replications at research farm BRRI, Gazipur during T Aman (rain fed condition) 2018. Individual plot size of each entry was $10 \mathrm{~m}^{2}$. The seeds were fully soaked in water for 24 hours for appearance of small shoots at the end of the seed. The pre-germinated seeds were sown in the seedbed. The seedlings were allowed to grow for 21 days in the seedbed before transplanting it to the field on 18 July, 2018. A single seedling per hill at 21 days was manually transplanted to the 
rice field. A standard spacing was maintained for planting which were row to row and plant-to-plant $20 \mathrm{~cm}$ and $15 \mathrm{~cm}$, respectively. Fertilizers were applied at the rate of 150:100:70 kg N: P: K and 60:10 kg Gypsum: ZnSO4, respectively per hectare. Except $\mathrm{N}$, all fertilizers were applied as basal dose during final land preparation. Nitrogen fertilizer was applied as top-dressed at the splits of 15, 30 and 45 days after transplanting. Intercultural operation, disease management and pest control measures were followed during the crop growth period.

\section{Data collection}

The data were recorded for ten quantitative traits viz., days to maturity, plant height $(\mathrm{cm})$, effective tillers per hill, panicle length $(\mathrm{cm})$, total number of spikelet's per panicle, number of filled spikelet's per panicle, number of unfilled spikelet's per panicle, spikelet fertility (\%), 1000-grain weight (g) and grain yield $\left(\right.$ tha $\left.^{-1}\right)$ based on Standard Evaluation System for rice (IRRI, 1996). Five plants were randomly selected from each plot excluding two border rows on both sides. Grain yield was adjusted at $14 \%$ moisture content.

\section{Statistical analysis}

Analysis of variance (ANOVA) was carried out using R program package (Ri386 4.0.1). The genetic parameters consisted of phenotypic variances $(\mathrm{Vp})$ and genotypic variances $(\mathrm{Vg})$, phenotypic coefficient of variation (PCV) and genotypic coefficient of variation (GCV), heritability (\%), genetic advance (GA) and genetic advance as percent of mean (GAM) were estimated following the formula given by Burton and Vane (1953) and Johnson et al. (1955).

\section{RESULTS AND DISCUSSION}

\section{Analysis of variance (ANOVA)}

The analysis of variance revealed that significant differences were present among the genotypes studied for all the traits viz., days to maturity, plant height $(\mathrm{cm})$, effective tillers per hill, panicle length $(\mathrm{cm})$, total number of spikelet's per panicle, number of filled spikelet's per panicle, number of unfilled spikelet's per panicle, spikelet fertility (\%), 1000-grain weight $(\mathrm{g})$ and grain yield $\left(\mathrm{t} \mathrm{ha}^{-1}\right)$, which indicates presence of adequate variability among the genotypes (Table 1). Thus, there is ample scope for the selection of various quantitative traits for rice improvement. Significant genetic differences among the rice genotypes were also reported by Bekele et al. (2013), Rashid et al. (2017), Abe be et al. (2017) and Gyawali et al. (2018). 
Table 1. Analysis of variance of promising rice hybrids for different traits (Mean square value)

\begin{tabular}{|c|c|c|c|c|}
\hline Sl No. & Traits & Replication & Treatment & Error \\
\hline 1 & Days to maturity & 3.84 & $132.69 * *$ & 4.41 \\
\hline 2 & Plant height (cm) & 11.36 & $358.78 * *$ & 3.95 \\
\hline 3 & Effective tillers/hill & 4.75 & $10.28 * *$ & 0.86 \\
\hline 4 & Panicle length $(\mathrm{cm})$ & 0.67 & $14.97 * *$ & 1.13 \\
\hline 5 & $\begin{array}{l}\text { Total number of } \\
\text { spikelet's/panicle }\end{array}$ & 10.18 & $2012.69 * *$ & 17.28 \\
\hline 6 & $\begin{array}{l}\text { Number of filled } \\
\text { spikelet's /panicle }\end{array}$ & 70.74 & $3066.21 * *$ & 27.17 \\
\hline 7 & $\begin{array}{l}\text { Number of unfilled } \\
\text { spikelet's/panicle }\end{array}$ & 4.94 & $412.49 * *$ & 7.37 \\
\hline 8 & $\begin{array}{l}\text { Spikelet fertility } \\
\text { percentage }(\%)\end{array}$ & 0.106 & $166.02 * *$ & 2.77 \\
\hline 9 & 1000-grain weight (g) & 0.19 & $29.06^{* *}$ & 0.25 \\
\hline 10 & Yield (t ha-1) & 0.18 & $4.36^{* *}$ & 0.05 \\
\hline
\end{tabular}

$* \& * *$ represent significant at $5 \%$ and $1 \%$, respectively

\section{Agronomic performance}

Mean value, coefficient of variation and standard deviation for 10 quantitative traits were presented in Table 2. It revealed that five genotypes for days to maturity, four genotypes for plant height, five genotypes for effective tillers, five genotypes for total number of spikelet's per panicle, six genotypes for filled grains per panicle, four genotypes for spikelet fertility percentage, four genotypes for thousand seed weight and three genotypes for grain yield showed higher value over their grand mean. Observing agronomic mean data, G3 produced highest grain yield followed by G6 and G9, whereas, G3, G6 and yielded $49 \% 23 \%$ and $10 \%$, respectively over the best check varieties. Yuan (1998) reported minimum 20-30 \% yield advantage for promising rice hybrids.

Therefore, the G3 and G6 are to be considered as superior promising and proposed to be extensively evaluated for further trial of variety release. These two genotypes also showed superior performance for the traits of effective tiller, panicle length, total number of spikelet's per panicle, number of filled spikelet's and spikelet's fertility percentage. 
Table 2. Agronomic performance of promising rice hybrids for quantitative traits

\begin{tabular}{|c|c|c|c|c|c|c|c|c|c|c|c|}
\hline $\begin{array}{l}\text { SL } \\
\text { No }\end{array}$ & Genotypes & DTM & $\mathrm{PH}$ & ET & PL & $\mathrm{SP} / \mathrm{P}$ & FG/P & UFS/P & $\begin{array}{l}\text { SF } \\
(\%)\end{array}$ & TSW & GY \\
\hline 1 & G1 & 107 & 98 & 7 & 24 & 195 & 152 & 42 & 78 & 25 & 5.5 \\
\hline 2 & G2 & 107 & 107 & 6 & 24 & 189 & 142 & 47 & 75 & 23 & 5.4 \\
\hline 3 & G3 & 123 & 117 & 10 & 28 & 226 & 206 & 18 & 91 & 19 & 8.2 \\
\hline 4 & G4 & 106 & 88 & 5 & 21 & 162 & 123 & 39 & 76 & 27 & 5.2 \\
\hline 5 & G5 & 105 & 107 & 7 & 24 & 174 & 142 & 32 & 81 & 21 & 5.3 \\
\hline 6 & G6 & 113 & 115 & 8 & 26 & 216 & 188 & 28 & 87 & 23 & 6.8 \\
\hline 7 & G7 & 104 & 108 & 5 & 22 & 168 & 117 & 51 & 69 & 27 & 4.5 \\
\hline 8 & G8 & 102 & 108 & 5 & 20 & 145 & 95 & 50 & 65 & 24 & 3.6 \\
\hline 9 & G9 & 118 & 128 & 8 & 25 & 205 & 168 & 37 & 82 & 31 & 6.1 \\
\hline 10 & $\begin{array}{l}\text { G10 (BRRI hybrid } \\
\text { dhan4) }\end{array}$ & 117 & 110 & 4 & 26 & 187 & 156 & 31 & 76 & 24 & 4.6 \\
\hline 11 & $\begin{array}{l}\text { G11 (BRRI hybrid } \\
\text { dhan6) }\end{array}$ & 112 & 121 & 4 & 25 & 220 & 163 & 58 & 74 & 24 & 5.5 \\
\hline \multicolumn{2}{|c|}{ Grand Mean } & 110 & 110 & 6 & 24 & 190 & 150 & 39 & 78 & 24 & 5.5 \\
\hline \multicolumn{2}{|c|}{ Coefficient of variation } & 6 & 10 & 30 & 10 & 14 & 21 & 30 & 10 & 13 & 23 \\
\hline \multicolumn{2}{|c|}{ Standard deviation } & 7 & 11 & 2 & 2 & 26 & 32 & 12 & 7 & 3 & 1 \\
\hline \multicolumn{2}{|c|}{ Standard error } & 2 & 3 & 1 & 1 & 8 & 10 & 4 & 2 & 1 & 0.4 \\
\hline \multicolumn{2}{|c|}{ Critical difference $(0.05)$} & 5 & 8 & 1 & 2 & 20 & 25 & 9 & 6 & 2 & 1 \\
\hline
\end{tabular}

$\mathrm{DM}=$ Days to maturity, $\mathrm{PH}=$ Plant height $(\mathrm{cm}), \mathrm{ET} / \mathrm{H}=$ Effective tillers per hill, $\mathrm{PL}=\mathrm{Panicle}$ length $(\mathrm{cm}), \mathrm{SP} / \mathrm{P}=$ Total number of spikelet's per panicle, $\mathrm{FG} / \mathrm{P}=$ Number of filled spikelet's per panicle, UFS/P= Unfilled spikelet's per panicle, $\mathrm{SF}(\%)=$ Spikelet's fertility percentage, TSW=1000-grain wt. (g) and GY= Yield (t ha-1)

\section{Estimation of genetic parameters}

Estimates range, phenotypic variances $(\mathrm{Vp})$ and genotypic variances $(\mathrm{Vg})$, phenotypic coefficient of variation (PCV) and genotypic coefficient of variation $(\mathrm{GCV})$, broad sense heritability $\left(\mathrm{h}^{2}\right) \%$ and genetic advance (GA) for all the traits are presented in Table 3.

\section{Genetic Variability}

The highest $\mathrm{Vp}$ and $\mathrm{Vg}$ were recorded for the traits of number of filled spikelet's /panicle (1040.11 and 1012.94), respectively. The lowest values of Vp and Vg were recorded for the traits of grain yield (1.49 and 1.44), respectively. The magnitude of phenotypic variance $(\mathrm{Vp})$ was higher than genotypic variance $(\mathrm{Vg})$ for all traits but difference is low indicating the presence of environmental influence to some extent in the phenotypic expression of the traits. Similarly, the phenotypic coefficient of variation (PCV) was slightly higher than genotypic coefficient of variation (GCV) for all studied traits. According to Sivasubramaniam and Menon (1973) PCV and GCV values $\geq 20 \%$ are regarded as high, between 10 and $20 \%$ to be moderate and $\leq 10 \%$ are considered as low. Based on this delineation, the traits effective tillers per hill $(31.99 \%)$, number of unfilled spikelet's per panicle $(30.23 \%)$, grain yield $(22.49 \%)$ and number of filled spikelet's per panicle $(21.49 \%)$ belonged to the category high. With regard to, high estimates of PCV for effective tillers per hill 
were reported by Ganga shetty et al. (2013), Neha et al. (2014), Bagudam et al. (2018). High estimates of PCV for number of unfilled spikelet's per panicle observed by Islam et al. (2016). For grain yield the results are in agreement with Neha et al. (2014) and Singh and Chaudhari (2019). For the number of filled spikelet's per panicle, high estimates of PCV was reported by Khatun et al. (2015) and Devi et al. (2016) and Harsha et al. (2017). In similar to our findings, does indicate the direct selection of genotypes could be done through these traits. The extent of PCV and GCV values were moderate to low ranged from $13.76 \%$ for number of spikelet's per panicle and $5.89 \%$ for days to maturity. Such observation earlier reported by Mishu et al. (2016), which recommended that selection could be postponed for these traits until to increase the gene flow and to fix favorable alleles. The current study also revealed that $\mathrm{Vp}$ and PCV were higher than theirs corresponding $\mathrm{Vg}$ and GCV respectively for all the traits, indicated the genotypes under the genetic control and influence of the environmental factors were less on the expression of traits. As the traits were less influenced by the environment, the traits can be used for selection. Similar findings were earlier reported by Vanisreeet al. (2013), Malimar et al. (2015), Rashid et al. (2017) and Gyawali et al. (2018).

Table 3. Range, phenotypic ( $\mathrm{Vp}$ ) and genotypic variance (Vg), phenotypic coefficient of variability (PCV) and genotypic coefficient of variability $(\mathrm{GCV})$, broad sense heritability $\left(\mathrm{h}^{2}\right)$ and genetic advance (GA) for observed traits

\begin{tabular}{|c|c|c|c|c|c|c|c|c|}
\hline \multirow[t]{2}{*}{$\begin{array}{l}\text { SL } \\
\text { No. }\end{array}$} & \multirow[t]{2}{*}{ Traits } & \multirow[t]{2}{*}{ Range } & \multirow[t]{2}{*}{ Vp } & \multirow[t]{2}{*}{$\mathrm{Vg}$} & \multicolumn{2}{|c|}{$\begin{array}{l}\text { Coefficient of } \\
\text { variation }(\%)\end{array}$} & \multirow[t]{2}{*}{$\begin{array}{l}\mathrm{h}^{2} \\
(\%)\end{array}$} & \multirow[t]{2}{*}{ GA } \\
\hline & & & & & PCV & GCV & & \\
\hline 1 & Days to maturity & $102-123$ & 42.22 & 37.80 & 5.89 & 5.57 & 89.54 & 11.98 \\
\hline 2 & Plant height $(\mathrm{cm})$ & $88-128$ & 122.23 & 118.28 & 10.07 & 9.91 & 96.77 & 22.04 \\
\hline 3 & Effective tillers/hill & $4-10$ & 4.00 & 3.14 & 31.99 & 29.43 & 78.60 & 3.24 \\
\hline 4 & Panicle length $(\mathrm{cm})$ & $20-28$ & 5.75 & 4.61 & 9.95 & 8.91 & 80.18 & 3.96 \\
\hline 5 & $\begin{array}{l}\text { Total number of } \\
\text { spikelet's/panicle }\end{array}$ & $145-226$ & 682.42 & 665.14 & 13.76 & 13.59 & 97.47 & 52.45 \\
\hline 6 & $\begin{array}{l}\text { Number of filled } \\
\text { spikelet's /panicle }\end{array}$ & $95-206$ & 1040.11 & 1012.94 & 21.49 & 21.21 & 97.39 & 64.70 \\
\hline 7 & $\begin{array}{l}\text { Number of unfilled } \\
\text { spikelet's/panicle }\end{array}$ & $18-58$ & 142.41 & 135.04 & 30.23 & 29.43 & 94.82 & 23.31 \\
\hline 8 & $\begin{array}{l}\text { spikelet fertility } \\
\text { percentage }(\%)\end{array}$ & $65-91$ & 57.19 & 54.42 & 9.73 & 9.49 & 95.14 & 14.82 \\
\hline 9 & $\begin{array}{l}\text { 1000-grain weight } \\
(\mathrm{g})\end{array}$ & $18.2-31.4$ & 9.85 & 9.61 & 13.04 & 12.87 & 97.47 & 6.30 \\
\hline 10 & Grain yield $\left(\mathrm{t} \mathrm{ha}^{-1}\right)$ & $3.5-8.3$ & 1.49 & 1.44 & 22.49 & 22.08 & 96.44 & 2.43 \\
\hline
\end{tabular}

\section{Heritability}

Heritability is a good index of the transmission of characters from parents to their offspring. The estimates of heritability can be utilized for prediction of genetic gain and its predictive role to indicate the reliability of the phenotypic value as a guide to breeding value. Heritability was classified as low (below $30 \%$ ), medium (30-60\%) 
and high (above $60 \%$ ) as suggested by Johnson et al. (1955). In the present study high heritability were observed for all the traits, estimates ranging from $78.60 \%$ for effective tillers per hill to $97.47 \%$ for total number of spikelet's per panicle and1000-grain weight simultaneously due to genetic causes rather only by environmental effects. High heritability for all the traits in rice hybrids was reported by Hasan et al. (2019). Roy and Shil (2020). High heritability does not always indicate high genetic gain; high heritability along with high genetic advance should be used for selecting desired varieties.

\section{Genetic advance}

The heritability estimates alone include the effect of both additive and non-additive genes which cannot furnish complete practical importance unless it is studied with genetic advance. The estimates of genetic advance can help to understand the type of gene action of various polygenic characters. High heritability coupled with high GA was recorded in number of filled spikelet's per panicle (64.70), total number of spikelet's per panicle (52.45), number of unfilled spikelet's per panicle (23.31) and plant height (22.04) indicated that the little influence of environmental effects in the inheritance of these traits. These findings were supported earlier by Laxman et al., (2010) and Khatun et al. (2015) for one or more traits.

\section{Heritability coupled with Genetic advance as percent of mean (GAM)}

Genetic advance as percentage of mean (GAM) give more precise result in comparison genetic advance. Therefore, heritability estimation coupled with genetic advance as percent of mean is more effective for selection. Genetic advance as percent mean was categorized as low (0-10\%), moderate (10-20\%) and high ( $\geq 20$ $\%)$. The graphical representation of heritability and genetic advance as percent of mean is depicted in Figure 1. The moderate GAM was exhibited by spikelet fertility percentage $(19.06 \%)$ followed by panicle length $(16.43 \%)$ and days to maturity $(10.87 \%)$. The highest GAM was recorded in number of unfilled spikelet's per panicle $(59.04 \%)$ followed by effective tillers per hill $(51.80 \%)$, grain yield (44.67 $\%)$, number of filled spikelet's per panicle (43.11\%), total number of spikelet's per panicle $(27.63 \%), 1000$ - grain weight $(26.18 \%)$ and plant height $(20.08 \%)$ which earlier supported by Laxuman et al. (2010) and Khatun et al. (2015) for one or more traits. The present findings are in conformity with the reports of Bagudam et al. (2018) for plant height, number of tillers per plant, grain number, test weight and plot yield in 46 rice genotypes. Chakra arty et al. (2019) reported similar results for effective tiller number, filled grains per panicle, unfilled spikelet's per panicle and grain yield. High heritability with high GAM indicated that these traits were governed by additive gene action and selection may be fruitful for those traits. 


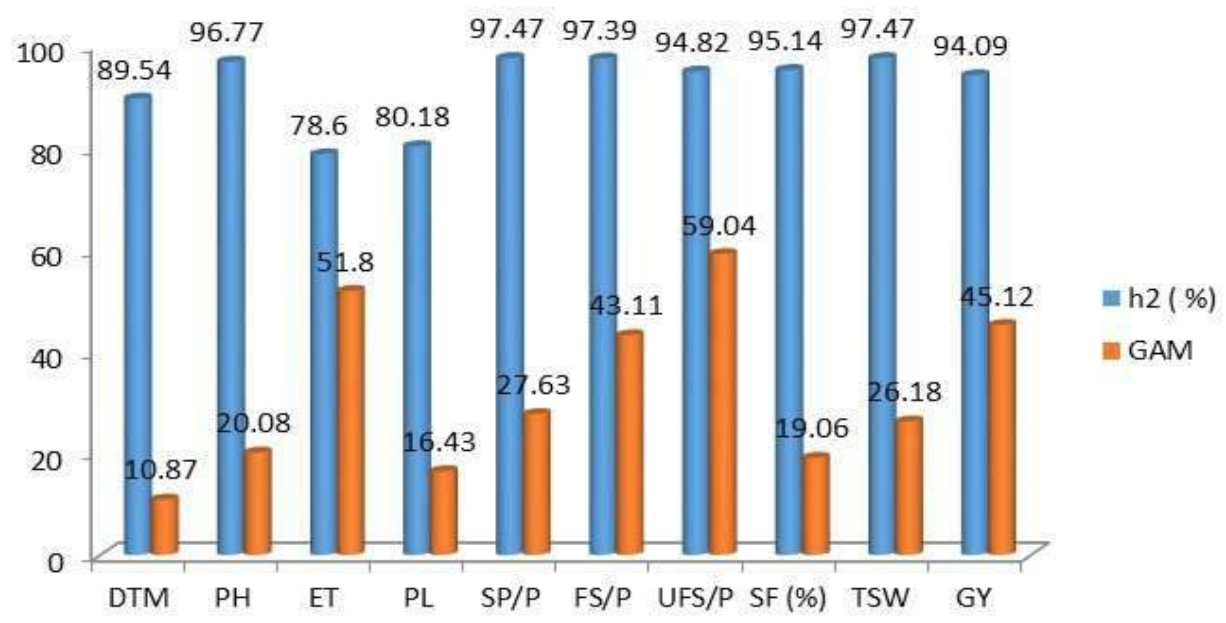

Figure 1. Graphical representation of heritability as broad sense $\left(\mathrm{h}^{2}\right) \%$ and genetic advance as mean percent (GAM)

\section{CONCLUSION}

The estimation of genetic parameters in some promising rice hybrids implied that number of filled spikelet's per panicle had high phenotypic and genotypic variance with high heritability and high genetic advance. Total number of spikelet's per panicle, number of unfilled spikelet's per panicle and plant height also showed high phenotypic and genotypic variance with high heritability and high genetic advance. This study also finds out the most promising rice hybrids G3 (IR79156A $\times$ EL108R) and G6 (IR79156A $\times$ EL253R) based on yield and all other yield related traits and it could be released as a variety after conducting necessary yield trials.

\section{REFFERENCES}

Abebe, T., Alamerew, S. and Tulu, L. (2017). Genetic variability, heritability and genetic advance for yield and its related traits in rain fed lowland rice (Oryza sativa L.) genotypes at Fogera and Pawe, Ethiopia. Advances in Crop Science and Technology, 5:272.

AIS. (2018). Krishi Diary 2016, Agricultural Information Service, Khamarbari, Farmgate, Dhaka-1215, Bangladesh.

Bagudam, R., Eswari, K. B., Badri, J. and Rao, P.R. (2018). Variability, heritability and genetic advance for yield and its component traits in NPT core set of rice (Oryza sativa L.). Electronic Journal of Plant Breeding, 9(4):1545-1551.

Bekele, B.D., Naveen, G.K., Rakhi, S. and Shashidhar, H.E. (2013). Genetic evaluation of recombinant inbred lines of rice (Oryza sativa L.) for grain zinc 
concentrations, yield related traits and identification of associated SSR markers. Pakistan Journal of Biological Science, 16(23):1714-1721.

Burton, G.W. and De-Van E.H. (1953). Estimating heritability in Tall Fescue (Fescuta arundinacea) from replicated clonal material. Agronomy Journal, 45: 481-487.

Chakrabarty, T., Islam, M.Z., Akter, N. and Khalequzzaman, M. (2019). Variability, traits association and path coefficient of yield and yield contributing traits of selected boro rice (oryza sativa L.) germplasm. SAARC Journal of Agriculture, 17(2):103-116

Childs, N.W. (2004). Production and utilization of rice. In: Rice Chemistry and Technology. St. Paul (ed. Champagne ET), American Association of Cereal Chemists Inc. Pp. 1-25

Devi, K.R., Parimala, K., Venkanna, V., Lingaiah, N., Hari, Y and Chandra, B.S. (2016). Estimation of variability for grain yield and quality traits in rice (Oryza sativa L.). International Journal of Pure \& Applied Bioscience, 4(2): 250-255.

Gangashetty, P., Salimath, P. and Hanamaratti, N. (2013). Genetic variability studies in genetically diverse non-basmati local Aromatic genotypes of rice (Oryza sativa L). Rice Genomics and Genetics, 4(2):4-8

Gyawali, S., Poudel, A. and Poudel, S. (2018). Genetic variability and association analysis in different rice genotypes in mid hill of western Nepal. Acta Scientific Agriculture, 2(9):69-76.

Harsha, D.I., Kumar, S. and Talha, M. (2017). Assessment of genetic variability and inter-character association studies in rice genotypes (Oryza sativa L.). International Journal of Current Microbiology and Applied Sciences. 6(9): 2041-2046.

Hasan, M.J., Kulsum, M.U., Mohiuddin, S.J. and Zahid-Al-Rafiq, M. (2019). Genetic interrelationship among yield and its components in rice hybrids. Bangladesh Journal of Botany, 48(4):1207-1213.

IRRI. (1996). Standard evaluation system for rice. 4th Edn., International Rice Research Institute, Manila, Philippines.

Islam, M.Z., Khalequzzaman, M., Bashar, M.K., Ivy, N.A., Haque, M.M. and Mian, M.A.K. (2016).Variability assessment of aromatic and fine rice germplasm in Bangladesh based on quantitative traits. The Scientific World Journal. doi.org/10.1155/2016/2796720.

Johnson, H.W., Robinson, H.F. and Comstock, R.E. (1955). Estimates of genetic and environmental variability in soybean. Agronomy Journal, 47:314-318.

Khatun, T., Hanafi, M.M., Yusop, M.R., Wong, M.Y., Salleh, F.M. and Ferdous, J. (2015). Genetic variation, heritability and diversity analysis of upland rice 
(Oryza sativa L.): Genotypes based on quantitative traits. Bio Med Research International, 1-7.

Larik, A.S. and Rajput, L.S. (2000). Estimation of selection indices in Brassica juncea L. and Brassica napus L. Pakistan Journal of Botany, 32(2):323-330.

Laxmi, S. and Chaudhari, P.R. (2019). Genetic studies of yield variation and association analysis in rice (O. sativa L.) genotype. International Journal of Current Microbiology and Applied Science, 8(3):2451-2457.

Laxuman, L.P., Salimath and Shashidhar, H. (2010). Analysis of genetic variability in inter-specific backcross inbred lines in rice (Oryza sativa L.). Karnataka Journal of Agricultural Sciences, 23:563-565.

Mallimar, M., Surendra, P., Hanamaratti, N.G., Jogi, M., Sathisha, T.N. and Hundekar, R. (2015). Genetic variability for yield and yield attributing traits in F3 generation of rice (Oryza sativa L.). Research in Environment and Life Sciences, 9(1):24-28.

Mishu, M.F.K., Rahman, M.W., Azad, M.A.K., Biswas, B.K., Talukder, M.A.I., Kayess, M.O., Islam, M.R and Alam, M.R. (2016). Study on Genetic variability and character association of aromatic rice (Oryza sativa L.) Cultivars. International Journal of Plant and Soil Science, 9(1):1-8.

Miura, K., Ashikari, M. and Matsuoka, M. (2011). The role of QTLs in the breeding of high-yielding rice. Trends in Plant Science, 16:319-26.3.

Neha, S., Babu, S., Singh, G., Ramlakhan, O.N. Sudhir, V., Monalisa, K.P., Debarchana, B. and Madhu, C. (2017). Genetic variation, heritability and diversity analysis of exotic upland rice (Oryza sativa L.) germplasms based on quantitative traits. The Journal of Pharmaceutical Innovation, 6(12):316-320.

Qian, Q., Guo, L., Smith, S.M. and Li, J. (2016). Breeding high-yield superior quality hybrid super rice by rational design. National Science Review, 3:283294.

R Core Team. (2013). R: A language and environment for statistical computing. R Foundation for Statistical Computing, Vienna, Austria.

Rashid, M.M., Nuruzzaman, M., Hassan, L. and Begum, S.N. (2017).Genetic variability analysis for various yield attributing traits in rice genotypes. Journal of Bangladesh Agricultural University, 15(1):15-19.

Roy, S.C. and Shil, P. (2020). Assessment of genetic heritability in rice breeding lines based on morphological traits and caryopsis ultrastructure. Scientific Reports, 10:7830.

Sivasubramanian, S. and Menon, M. (1973). Heterosis and inbreeding depression in rice. Madras Agricultural Journal, 60:1139. 
Vanisree, S., Swapna, K., Damodar Raju, Ch., Surender Raju, Ch. and Sreedhar, M. (2013). Genetic variability and selection criteria in rice. Journal of Biological Science, 1(4):342-346.

Yuan, L P. (1998). Hybrid rice breeding in China. In: Advances in Hybrid Rice Technology (Virmani SS, Siddiq EA, Muralidharan K, editors). Proceedings

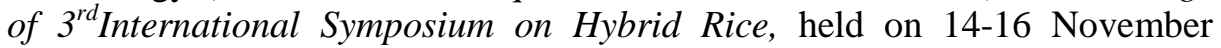
1996, Hyderabad, India. Pp. 27-33. 